느타리, 새송이 및 팽이버섯 폐배지의 반추동물 조사료원으로서의

\author{
사료 영양적 가치평가 \\ 배지선* . 김영일* . 정세형* . 오영균** . 곽완섭* \\ 건국대학교 자연과학대학 생명자원환경과학부 축산학전공* \\ 축산연구소 영양생리과**
}

\title{
Evaluation on Feed-Nutritional Value of Spent Mushroom (Pleurotus osteratus, Pleurotus eryngii, Flammulina velutupes) Substrates as a Roughage Source for Ruminants
}

\author{
J. S. Bae*, Y. I. Kim*, S. H. Jung*, Y. G. Oh** and W. S. Kwak* \\ Animal Science, School of Life Resource and Environmental Sciences College of Natural Sciences, \\ Konkuk University*, National Livestock Research Institute, R. D. A**
}

\begin{abstract}
This study was conducted to evaluate the feed-nutritional value of spent mushroom substrates(SMS) as a roughage source for ruminants through in vitro and in situ experiments. The SMS was classified into a roughage source with high fiber(NDF $64 \sim 78 \%$ ) and low protein(CP $7-11 \%$ ). The chemical composition of SMS was affected mainly by the primary culture ingredient rather than mushroom species. Compared with sawdust-SMS, cotton waste-SMS contained less $(\mathrm{P}<0.05)$ NDF and more $(\mathrm{P}<0.05)$ nonfibrous carbohydrate and ash $(\mathrm{P}<0.05)$. In vitro DM and NDF disappearances were high in the order of corn cob-, cotton waste-, and sawdust-SMS, in situ DM, NDF and ADF disappearances at 24hr incubation also showed the same pattern with in vitro trials. Compared with sawdust-SMS, cotton waste-SMS had higher digestible fractions and lower non-digestible fractions of $\mathrm{NDF}$ and $\mathrm{ADF}(\mathrm{P}<0.05)$, resulting in higher in situ $\mathrm{DM}$ and $\mathrm{NDF}$ disappearances $(\mathrm{P}<0.05)$ and higher ruminal degradability $(\mathrm{P}<0.05)$. Therefore, the preferential use of cotton waste-SMS to sawdust-SMS is recommended as a roughage source for ruminants.
\end{abstract}

(Key words: Spent mushroom substrate, Spent mushroom compost, Recycling, Feed, Nutrition, Roughage)

I . 서 론 이로 인해 농촌 주변지역에서의 환경오염 문제 가 대두되고 있는 실정이다.

2004년 한국에서는 156,000여 M/T의 버섯이 버섯 배지의 원료는 버섯 종류 및 재배 방식 생산되었고(농림부, 2005), 재활용가능성이 높은 느타리, 새송이, 팽이버섯 폐배지의 발생량은 에 따라 다양하지만 배지 주원료에 따라서 폐 면(cotton waste), 옥공이(corn cob), 볏짚 그리고 약 105 만 $\mathrm{M} / \mathrm{T}$ 정도인 것으로 자체 계산되며, 톱밥 주원료로 분류되며, 주원료에 미강, 밀기

본 연구는 2004년도 건국대학교 학술진흥연구비 지원에 의한 논문임.

Corresponding author: Wan-Sup Kwak, School of Life Resource and Environmental Sciences, College of Natural Sciences, Konkuk University, Chung-Ju, Chung-Buk, 380-701, Korea.

Tel : 82-43-840-3521, e-mail : wsk@kku.ac.kr 
울, 비트펄프, 면실피, 면실박, 건비지 등의 부 원료를 첨가한 배지에서 버섯을 생산하고 있 다. 버섯 배지의 구성 물질은 대부분이 사료 원료로도 이용될 수 있는 것이며, 현장에서 추 정하는 대로 버섯 재배 과정에서 배지 영양분 의 약 $20 \%$ 정도는 버섯에 의해 이용이 되고, $80 \%$ 는 폐배지에 그대로 남아있다면(Williams 등, 2001) 폐배지는 여전히 사료적 가치가 있을 것으로 예상된다.

국내 연구에서 팽이버섯 폐배지의 화학적 조 성은 neutral detergent fiber (NDF) 73.4\%, crude ash $8.3 \%$, crude protein (CP) $11.5 \%$ 의 수준이었 으며(정, 2003), 표고버섯 폐골목은 NDF 63.1\% (송과 조, 1997), 또는 83.9\%(임 등, 1998)로써 폐배지는 고섬유성이며 성분의 변이가 높았다.

인도의 연구에서 볏짚 주원료 폐배지의 화학 적 조성은 $\mathrm{NDF}$ 82.4\%, acid detergent fiber (ADF) 56.2\%, crude ash 24.3\%, CP 5.0\% 수준 이었으며(Kahlon and Dass, 1987), 밀짚 주원료 폐배지의 경우 $\mathrm{NDF} 59.6 \%, \mathrm{ADF} 46.0 \%, \mathrm{CP}$ 8.4\% 이었고(Gupta and Langar, 1988), 특히 미 국에서는 배지 조제 간 Gypsum(석회)과 탄산칼 슘을 첨가하기 때문에 조회분 함량이 너무 높 아 동물 사료로의 이용이 불가능하나(Governot, 1997) 국내에서 발생되는 폐배지는 조회분 함 량이 $10 \%$ 내외로 낮아서 반추동물 사료로서 잠재적 가치가 매우 높다고 하겠다. 또한 버섯 배지에 균사체를 접종하고 배양하는 과정에서 일부 균사체(mycelium)는 lignin과 cellulose의 결 합을 분해할 수 있는 능력을 가지고 있다는 보 고(김과 김, 1993; Hadar at all., 1993)와 톱밥에 표고버섯균 처리가 lignin 분해 효과(약 50\%)가 있다는 보고(윤, 1996)도 있으며, 버섯 균사체는 다량의 단백질로 구성되어 있어 미생물 균체 자체도 단세포 단백질의 사료가 될 수 있으며, 균사체가 반추위 미생물에 필요한 영양물질이 될 수도 있다는 보고(Caswell, 1990)도 있다. 그 러나 배출되는 폐배지는 주로 농가주변에 방치 되거나 수거 운송되어 최종적으로 거름으로 사 용이 되며, 대량 발생되는 폐배지의 경우 돈분 발효퇴비 제조 시 수분조절제로 사용되기도 하 고, 극히 일부 우사바닥 깔개로 이용되기도 한
다. 그러나 폐배지는 충분히 반추가축의 조사 료원으로 사용될 수 있음에도 불구하고 이에 대한 과학적 연구는 매우 미흡한 실정이다.

국내에서는 표고버섯 폐골목 및 팽이버섯 폐 배지의 사료화 연구(정, 2003; 송과 조, 1997; 임 등, 1998)는 이루어 졌으나, 느타리버섯과 새송이버섯의 폐배지에 대한 반추가축 사료화 연구는 거의 없으며, 특히 버섯 종류별, 주원료 별 폐배지에 대한 사료 영양적 가치에 대한 비 교 평가는 이루어지지 않고 있다.

따라서 본 연구에서는 느타리, 새송이 및 팽 이버섯 폐배지를 버섯 종류별, 배지에 이용된 주원료별로 나누어 반추가축 사료로서의 영양 적 가치를 구명하기 위해서 화학성분, in vitro 소실율 실험 및 in situ darcon bag 실험을 수행 하였다.

\section{ㅍ. 재료 및 방법}

\section{1. 버섯농장 현장조사 및 시료 채취}

충북 지역에서 발생되는 버섯 재배 부산물의 발생 현황, 화학적 특성 및 사료적 가치를 평 가하기 위해 버섯의 종류별, 배지의 주원료별 및 재배 방식별로 충북 충주시, 청원군, 음성 군, 괴산군, 진천군 지역에서 2004년 10월부터 2005년 3월까지 6개월에 걸쳐서 버섯농장 34곳 을 현장 방문하여 배지 주원료로서 톱밥 9점, 폐면 4점, 볏짚 4점, 옥공이 4점을 채취하였고, 버섯 폐배지에 있어서는 폐면 주원료 폐배지 15점, 톱밥 주원료 폐배지 29점, 볏짚 주원료 폐배지 1점, 옥공이 주원료 폐배지 4점을 확보 하였으며, 총 70 점의 시료를 채취하였다.

모든 시료는 채취 전에 외관적 모습, 냄새, 배지의 주원료 및 물리적 특성에 관하여 관찰 기록하였으며, 대표적 시료를 확보하기 위하여 채취 시에는 균상 재배의 경우 여러 위치에서 조금씩 무작위 채취를 하여 $1 \mathrm{~kg}$ 을 채취하였으 며, 병 재배 및 봉지 재배의 경우 각각의 봉지 또는 병을 2 3개씩 철저히 혼합하여 $1 \mathrm{~kg}$ 정도 를 채취하여 밀봉이 가능한 비닐봉지에 담아 얼음이 담겨있는 아이스박스에 보관하였으며, 
신속히 실험실로 운반하여 향후 화학적 성분을 분석하기 위하여 $-20^{\circ} \mathrm{C}$ 냉동실에서 저장, 보관 하였다.

\section{2. 화학분석}

화학분석시 시료는 $105^{\circ} \mathrm{C}$ 에서 24 시간 건조 후 Sample Mill(Cemotec, Tecator, Sweden)을 이 용하여 $1 \mathrm{~mm}$ 크기로 분쇄하여 분석에 이용하였 다. dry matter $(\mathrm{DM}), \mathrm{CP}(\mathrm{N} \times 6.25)$, ether extract (EE)는 $\mathrm{AOAC}(1990)$ 의 방법에 따라, $\mathrm{NDF}, \mathrm{ADF}$ 는 Van Soest 등(1991)의 방법에 따라 분석하였 다. Organic matter $(\mathrm{OM})$ 는 100 에서 crude ash를 뺀 값으로, hemicellulose는 $\mathrm{NDF}$ 에서 $\mathrm{ADF}$ 를 뺀 값으로, non-fibrous carbohydrate (NFC)는 100$(\mathrm{NDF} \%+\mathrm{CP} \%+\mathrm{EE} \%+$ crude ash\%)의 공식에 의해 구하였다. 비소화성 단백질(ADF-CP)은 산 세제용액을 처리 후 $\mathrm{CP}$ 를 측정하였다. True protein (TP)은 5\% trichloroacetic acid 용액에서 침전되는 양으로, non-protein nitrogen $(\mathrm{NPN})$ 은 $\mathrm{CP}$ 에서 $\mathrm{TP}$ 를 뺀 값으로 하였다. Lignin은 Van Soest 등(1991)의 방법에 따라 산세제용액 처리 후 $72 \%$ 농축황산을 처리하여 회화과정을 통해 분석하였고, cellulose는 $\mathrm{ADF}$ 에서 lignin을 뺀 값 으로 구하였다.

\section{In vitro disappearance 실험}

In vitro technique는 Tilley and Terry(1963)의 two stage in vitro technique를 이용하였다. 1차 실험으로 배지 주원료의 $\mathrm{DM}, \mathrm{NDF}$ 의 소실율 (disappearance)을 분석하였고, 2차 실험에서는 화학성분이 다양한 주원료별 버섯 폐배지를 $\mathrm{NDF}$ 함량에 따라 분류하여 NDF 함량이 비슷 한(NDF 71.6 $\pm 6.0 \%$ ) 시료를 선발하여 $\mathrm{DM}, \mathrm{NDF}$ 의 소실율 분석에 사용하였다. 톱밥주원료 폐 배지는 주원료인 톱밥이 $50 \sim 80 \%$ 범위에서 사 용이 되었으며, 나머지 20 50\%는 부원료로 구 성이 되었다. 콘코브 및 폐면 주원료 폐배지는 주원료를 $100 \%$ 사용하였다. 반추위액은 충주시 도축장으로부터 한우 도축 직후 반추위에서 내 용물을 꺼내 4겹의 거즈(Gauze)로 걸러내어 보
온병에 넣어 실험실로 운반하고 실험실에서 다 시 4겹의 거즈로 걸러내어 반추위액을 분리하 여 사용하였다.

\section{In situ dacron bag 실험}

In situ 실험은 축산연구소 가축대사실험실에 서 반추위 cannula가 장착된 평균 체중 $465 \mathrm{~kg}$ 의 한우 거세우 2 두를 이용하여 실시하였다. 실험을 위해 2주간의 적응기간을 두었으며, 급 여사료는 옥수수 $30.5 \%$, 대두피 $6.1 \%$, 밀기울 $10.7 \%$, 대두박 $6.1 \%$, calcium phosphate $0.2 \%$, limestone $0.6 \%$, vitamin-mineral premix $0.2 \%$ 및 오차드그라스 $45.6 \%$ 로 구성된 사료(DM 98.1\%, CP 12.3\%, EE 2.3\%, NDF 38.9\%, ADF $24.7 \%$ 및 ash 6.1\%)를 일일 $8 \mathrm{~kg}$ 씩 이등분하여 09:00, 17:00에 급여하였다. 물과 미네랄블럭은 자유섭 취토록 하였다. in situ dacron bag 배양은 Ørskov 등(1980)의 방법에 따라 실시하였다. 분석에 사용된 시료는 in vitro에 사용된 시료와 동일 하며, 주원료별로 분류하여 처리별 4반복의 시 료를 Thomas Whilley mill(Thomas Scientific, Model4, New Jersey, U.S.A.)로 분쇄한 후 실험 용체(Siever No.20, No.70)를 이용하여 $2 \mathrm{~mm}$ 이 하의 입자도를 가진 시료를 선별하였다. 공시 축 당 2반복으로 총 4 반복을 두었으며, 가로 $10 \mathrm{~cm}$, 세로 $15 \mathrm{~cm}$ 의 dacron bag(pore size $45 \mu$ $\mathrm{m})$ 을 사용하여 bag 당 $3 \mathrm{~g}$ 의 시료를 넣은 후 반추위의 복낭(ventral sac) 부위에 $0,6,12,24$, 48,72 시간 동안 현수, 배양하였다. 각 배양 시 간대별의 bag을 꺼내어 흐르는 물에 30 분간 세 척한 후 $60^{\circ} \mathrm{C}$ 에서 48 시간 건조하여 $\mathrm{NDF}$ 및 $\mathrm{ADF}$ 를 분석하였다.

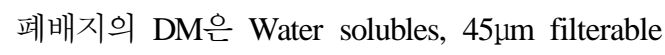
분획(fraction), insoluble digestible 분획과 nondigestible 분획으로 분류하였다(Armentano 등, 1986). NDF의 분획은 digestible 분획과 nondigestible 분획으로 분류하였다(Smith 등, 1971). $\mathrm{NDF}$ 는 72시간에 소화가 완료됨을 가정하였다. $\mathrm{NDF}$ 소화율 측정을 위한 linear model은 Nocek 과 English(1986)의 모델을 이용하였다. 배양 72 시간에 남아있는 부분은 non-digestible 분획으로 
하였다. 각 시간대별 잔존량에서 non-digestible 분획을 뺀 값을 \%로 전환 후 natural $\log$ 를 취 하여 linear regression을 평가하였다. 이때 기울 기 값을 degradation rate $(\% / h r)$ 로 하였다. $\mathrm{DM}$ 과 $\mathrm{NDF}$ 의 분해율 측정을 위한 모델로는 Mertens 와 Loften(1980)의 방법을 이용하였다.

\section{5. 통계 분석}

통계 분석을 위하여 General Linear Model Procedure(SAS, 2002)를 이용하였고, 3개 처리구 의 평균치는 Tukey's multiple range test(SAS, 2002), 2개 처리구의 평균치는 studentized-t test (SAS, 2002)를 이용하여 비교하였다. In vitro/situ $\mathrm{DM}$ 소실율 및 $\mathrm{NDF}$ 소실율과 화학성분 간의 상 관관계 분석을 위하여 Pearson correlation(SAS, 2002) 방법을 이용하였다.

\section{III. 결과 및 고찰}

\section{1. 버섯 종류별 주원료별로의 폐배지의 물리 화학적 특성}

본 실험에서 연구된 느타리버섯(Pleurotus osteratus), 새송이버섯(Pleurotus eryngii), 팽이버섯 (Flammulina velutupes)은 재배 방식에 따라 병 재배, 균상 재배, 봉지 재배로 구분 할 수 있었 다. 병 재배는 주원료로 톱밥을 $70 ~ 80 \%$ 사용 하였고, 균상 재배는 주원료로 폐면을 사용하 였으며, 봉지 재배의 경우는 주로 톱밥 $40 \pm$ $10 \%$ 에서 비트펄프, 면실박 또는 면실피를 부원 료로 사용하였다. 느타리버섯은 주로 균상 재 배, 봉지 재배이며, 새송이버섯과 팽이버섯은 병 재배를 하는 등 폐배지는 재배 방식에 따라 다양한 형태로 배출되고 있었다. 따라서 버섯

Table 1. Chemical composition (on DM basis) of spent mushroom substrates according to mushroom species and primary culture ingredients

\begin{tabular}{|c|c|c|c|c|c|c|c|c|c|c|}
\hline \multirow[b]{2}{*}{ Item } & \multicolumn{2}{|c|}{ Flammulina velutupes } & \multicolumn{4}{|c|}{ Pleurotus eryngii } & \multicolumn{4}{|c|}{ Pleurotus osteratus } \\
\hline & $\begin{array}{c}\text { Saw } \\
\text { dust } \\
(n=3)\end{array}$ & SD & $\begin{array}{c}\text { Saw } \\
\text { dust } \\
(n=11)\end{array}$ & SD & $\begin{array}{c}\text { Corn } \\
\text { cob } \\
(n=4)\end{array}$ & $\mathrm{SD}$ & $\begin{array}{c}\text { Saw } \\
\text { dust } \\
(n=15)\end{array}$ & SD & $\begin{array}{c}\text { Cotton } \\
\text { waste } \\
(\mathrm{n}=15)\end{array}$ & SD \\
\hline & & & & & $\%$ & & & & & \\
\hline Neutral detergent fiber & $77.8^{\mathrm{a}}$ & 6.4 & $78.2^{\mathrm{a}}$ & 4.1 & $72.4^{\mathrm{ab}}$ & 1.8 & $77.2^{\mathrm{a}}$ & 5.6 & $64.0^{\mathrm{b}}$ & 7.6 \\
\hline Acid detergent fiber & $62.8^{\mathrm{a}}$ & 12.0 & $60.4^{\mathrm{a}}$ & 6.3 & $42.8^{\mathrm{b}}$ & 2.2 & $66.3^{\mathrm{a}}$ & 4.5 & $60.9^{\mathrm{a}}$ & 6.9 \\
\hline Hemicellulose & $15.0^{\mathrm{bc}}$ & 5.7 & $17.8^{\mathrm{b}}$ & 3.9 & $29.6^{\mathrm{a}}$ & 0.8 & $10.8^{\mathrm{C}}$ & 2.2 & $3.1^{\mathrm{d}}$ & 2.2 \\
\hline Cellulose & 39.8 & 7.1 & 40.4 & 6.3 & 33.9 & 2.3 & 41.8 & 4.2 & 44.1 & 8.9 \\
\hline Lignin & $23.1^{\mathrm{a}}$ & 5.3 & $20.0^{\mathrm{ab}}$ & 3.3 & $8.9^{\mathrm{c}}$ & 0.7 & $24.6^{\mathrm{a}}$ & 3.1 & $16.7^{\mathrm{b}}$ & 4.2 \\
\hline Nonfibrous carbohydrate & $5.7^{\mathrm{b}}$ & 4.1 & $7.8^{\mathrm{ab}}$ & 2.1 & $12.2^{\mathrm{a}}$ & 2.3 & $5.0^{\mathrm{b}}$ & 4.0 & $12.9^{\mathrm{a}}$ & 4.2 \\
\hline Crude protein(CP) & $7.8^{\mathrm{bc}}$ & 0.5 & $7.2^{\mathrm{c}}$ & 2.2 & $7.7^{\mathrm{bc}}$ & 0.6 & $11.1^{\mathrm{a}}$ & 1.5 & $10.1^{\mathrm{ab}}$ & 1.7 \\
\hline True protein/CP & $63.0^{\mathrm{ab}}$ & 6.4 & $69.4^{\mathrm{ab}}$ & 6.8 & $58.6^{\mathrm{c}}$ & 4.5 & $72.6^{\mathrm{a}}$ & 10.4 & $63.9^{\mathrm{ab}}$ & 7.2 \\
\hline Non-protein N/CP & $37.0^{\mathrm{ab}}$ & 6.4 & $30.7^{\mathrm{ab}}$ & 6.8 & $41.4^{\mathrm{a}}$ & 4.5 & $27.4^{\mathrm{b}}$ & 10.4 & $36.1^{\mathrm{ab}}$ & 7.2 \\
\hline ADF-CP/CP & $31.1^{\mathrm{bc}}$ & 9.3 & $36.4^{\mathrm{abc}}$ & 6.9 & $27.0^{\mathrm{c}}$ & 1.2 & $51.9^{\mathrm{a}}$ & 10.3 & $47.5^{\mathrm{ab}}$ & 14.3 \\
\hline Ether extract & $2.2^{\mathrm{a}}$ & 1.6 & $2.1^{\mathrm{a}}$ & 0.9 & $2.2^{\mathrm{a}}$ & 0.1 & $0.5^{\mathrm{b}}$ & 0.1 & $1.3^{\mathrm{ab}}$ & 0.6 \\
\hline Crude ash & $6.5^{\mathrm{b}}$ & 1.1 & $4.7^{\mathrm{b}}$ & 1.3 & $5.6^{\mathrm{b}}$ & 0.1 & $6.2^{\mathrm{b}}$ & 2.3 & $11.7^{\mathrm{a}}$ & 2.8 \\
\hline Dry matter & $51.2^{\mathrm{a}}$ & 4.1 & $40.8^{\mathrm{b}}$ & 4.9 & $42.8^{\mathrm{ab}}$ & 2.1 & $35.8^{\mathrm{bc}}$ & 4.7 & $27.6^{\mathrm{c}}$ & 6.7 \\
\hline
\end{tabular}

a,b,c,d Means with different superscripts within the same row are significantly $\operatorname{different}(\mathrm{P}<0.05)$. 
의 종류에 따라 재배방식이 바뀌게 되고 이에 따라 사용되는 원료 또한 많은 차이가 생긴다. 이로 인해 발생되는 폐배지들 간에는 많은 성 분적 차이가 생기게 된다.

폐배지는 배출시 주원료의 입자를 유지하고 있었으며, 원료에 비해 폐배지는 갈색을 띠며 균사의 성장에 따른 흰색 균사체를 관찰할 수 있었으며, 봉지 재배와 병 재배의 경우는 균사 체가 폐배지에 골고루 퍼져있으며, 균상 재배 의 경우는 폐배지의 상층부에서 집중적으로 균 사체가 관찰되었다. 배출 직후에 폐배지의 표 면에서 곰팡이는 관찰되지 않았다. 폐배지 입자 의 굳기는 원료에 비해 약했으며, 버섯 고유의 향이 폐배지에 배어있었다. 밀도(wet density)는 재배방식에 따라 균상 재배 0.38, 병 재배 037, 봉지 재배가 $0.42(\mathrm{~g} / \mathrm{ml})$ 수준이었다(Table 미제 시).

건물함량은 느타리버섯 균상 재배 폐배지 $27.6 \%$ 에서 팽이버섯 병 재배 폐배지 $51.1 \%$ 까지 다양하게 배출되었으며 이는 배출되는 시기와 재배 방식에 따라 변이도가 높았다. 버섯 종류 별로 배출되는 폐배지의 화학적 성분은 Table 1 에 제시되어져 있다. 전반적으로 폐배지의 화 학적 성분의 분포는 $\mathrm{NDF} 64.0 \sim 78.2, \mathrm{ADF} 42.8$ $\sim 66.3$, hemicellulose 3.1 29.6, cellulose 33.9 44.1, lignin 8.9 24.6, NFC 5.0 12.9, OM 88.3 $\sim 95.3$, СР 7.2 11.1, ТP/CP 58.6 72.6, NPN/ CP 27.4 41.4, ADF-CP/CP 27.0 51.9, EE 0.5 $\sim 2.2$, ash $4.7 \sim 11.7 \%$ 로 나타났다. 즉 버섯 폐 배지는 고섬유소 저단백질 조사료원에 속하였 다.

주원료별로 폐배지의 특성을 살펴보면, 섬 유소 성분이 가장 높은 톱밥 주원료 폐배지와 비교해서 폐면 주원료 폐배지는 $\mathrm{NDF}$ 함량이 낮고 $(\mathrm{P}<0.05)$, 비섬유성탄수화물 $(\mathrm{NFC})$ 과 ash 함 량이 높으며 $(\mathrm{P}<0.05)$, 특히 $\mathrm{NDF}$ 의 대부분은 $\mathrm{ADF}$ 로 구성되는 특징이 있었다. 옥공이 주원 료 폐배지는 $\mathrm{NDF}$ 구성성분이 되는 $\mathrm{ADF}$ 와 lignin 함량이 현저히 낮고 $(\mathrm{P}<0.05), \mathrm{NFC}$ 함량 이 상대적으로 높은 $(\mathrm{P}<0.05)$ 특징이 있었다. 전 반적으로 폐배지는 단백질 함량이 낮고, 비소 화성 단백질(ADF-CP) 함량이 높아서 질이 매
우 떨어지는 것으로 나타났다. 참고로 발생량 이 매우 적은 볏짚 주원료 폐배지의 $\mathrm{NDF}$ 는 39.3, ADF 31.4, hemicellulose 7.9, cellulose 26.0 lignin 5.4, NFC 24.6, OM 72.4, CP 7.1, TP/CP 55.7, NPN/ CP 44.3, ADF-CP/CP 27.6, $\mathrm{EE} 1.4$, ash $27.6 \%$ 인 것으로 나타났다(Table 미 제시).

배지 주원료로 톱밥이 이용되는 경우 버섯 종류와 상관없이 폐배지의 화학적 성분의 평 균치는 유사하였다 $(\mathrm{P}>0.05)$. 즉 세포벽 구성물 질인 $\mathrm{NDF}, \mathrm{ADF}$, cellulose, lignin, $\mathrm{ADF}-\mathrm{CP}$ 와 그 외의 $\mathrm{NFC}, \mathrm{OM}, \mathrm{TP} / \mathrm{NPN}$, ash 성분은 비슷 하였다. 그리고 버섯 폐배지의 화학적 성분은 전반적으로 버섯 종류보다는 배지의 주원료 종류에 의해 주로 영향을 받았다. 덧붙여 폐배 지의 화학적 성분은 배지에 이용된 주원료 즉 폐면, 톱밥, 옥공이 등의 화학적 성분(data 미 제시)에 의해 크게 좌우 되었다. 그러나 분석 된 배지의 원료는 분석된 폐배지를 제조에 사 용된 것이라 볼 수 없기에 직접적인 비교는 힘들다.

\section{2. 배지 주원료별 폐배지와 배지원료의 in vitro DM, NDF 소실율}

배지 주원료별 폐배지의 in vitro 소실율은 Table 2와 같다. 폐배지의 $\mathrm{DM}$ 소실율과 $\mathrm{NDF}$ 소실율은 시간대별로 비슷한 변화 양상을 보 였으며, $\mathrm{DM}$ 과 $\mathrm{NDF}$ 소실율은 분석된 배양시 간(24, 48, 72시간) 모두에서 옥공이, 폐면, 톱 밥 순으로 높게 나타났다 $(\mathrm{P}<0.05)$. 특히 배양 72시간에서 톱밥 주원료 폐배지와 비교해서 옥공이 주원료 폐배지의 in vitro $\mathrm{DM}$ 과 $\mathrm{NDF}$ 소실율은 평균 3.5 배 정도로 높았으며, 폐면 주원료 폐배지의 in vitro $\mathrm{DM}$ 과 $\mathrm{NDF}$ 소실율 은 2 배 정도 높은 것으로 나타났다. 이러한 양 상은 원료의 in vitro $\mathrm{DM}, \mathrm{NDF}$ 소실율에 의해 크게 영향을 받는 것으로 보여졌다. 왜냐하면 배지원료의 $\mathrm{DM}, \mathrm{NDF}$ 소실율은 옥공이, 폐면, 톱밥 순으로 높았고 $(\mathrm{P}<0.05)$, 톱밥은 모든 항 목에서 대부분 소실이 되지 않는 것으로 나타 났기 때문이다. 참고로 볏짚 주원료 폐배지의 
Table 2. In vitro DM and NDF disappearance of culture ingredients and spent mushroom substrates(SMS) according to the primary culture ingredient ${ }^{1), 2)}$

\begin{tabular}{|c|c|c|c|c|}
\hline $\begin{array}{c}\text { Incubation } \\
\text { time, hr }\end{array}$ & Sawdust & $\begin{array}{l}\text { Corn } \\
\text { cob }\end{array}$ & $\begin{array}{l}\text { Cotton } \\
\text { waste }\end{array}$ & SE \\
\hline \multicolumn{5}{|c|}{$\ldots \ldots \ldots \ldots \ldots \ldots \ldots \% \%$} \\
\hline \multicolumn{5}{|c|}{ Spent Mushroom Substrate ${ }^{3)}$} \\
\hline \multicolumn{5}{|l|}{ DMD } \\
\hline 24 & $2.1^{\mathrm{c}}$ & $19.9^{\mathrm{a}}$ & $10.4^{\mathrm{b}}$ & 1.7 \\
\hline 48 & $10.2^{\mathrm{C}}$ & $37.4^{\mathrm{a}}$ & $18.3^{\mathrm{b}}$ & 3.2 \\
\hline 72 & $14.7^{\mathrm{C}}$ & $49.0^{\mathrm{a}}$ & $29.8^{\mathrm{b}}$ & 2.8 \\
\hline \multicolumn{5}{|l|}{ NDFD } \\
\hline 24 & $0.9^{c}$ & $18.4^{\mathrm{a}}$ & $10.0^{\mathrm{b}}$ & 1.3 \\
\hline 48 & $8.4^{\mathrm{c}}$ & $35.6^{\mathrm{a}}$ & $16.0^{\mathrm{b}}$ & 3.1 \\
\hline 72 & $13.2^{\mathrm{C}}$ & $47.5^{\mathrm{a}}$ & $30.1^{\mathrm{b}}$ & 2.5 \\
\hline
\end{tabular}

Culture ingredient

DMD

$\begin{array}{crrrr}24 & -2.5^{\mathrm{b}} & 35.4^{\mathrm{a}} & -10.4^{\mathrm{b}} & 2.1 \\ 48 & -2.7^{\mathrm{c}} & 55.8^{\mathrm{a}} & 23.2^{\mathrm{b}} & 1.7 \\ 72 & -2.5^{\mathrm{c}} & 62.5^{\mathrm{a}} & 32.0^{\mathrm{b}} & 2.9 \\ \text { NDFD } & & & & \\ 24 & -8.5^{\mathrm{b}} & 48.7^{\mathrm{a}} & -15.0^{\mathrm{b}} & 4.4 \\ 48 & -7.6^{\mathrm{c}} & 77.9^{\mathrm{a}} & 40.1^{\mathrm{b}} & 6.6 \\ 72 & -11.2^{\mathrm{b}} & 80.2^{\mathrm{a}} & 52.2^{\mathrm{a}} & 5.7\end{array}$

1) Means of 4 observations.

2) $\mathrm{DMD}=$ dry matter disappearance;

NDFD=neutral detergent fiber disappearance

3) Primary culture ingredients were $100 \%$ corn cob, 50 $80 \%$ sawdust depending upon samples, and 100\% cotton waste.

a,b,c Means with different superscripts within the same row are significantly different $(\mathrm{P}<0.05)$.

in vitro $\mathrm{DM}, \mathrm{NDF}$ 소실율은 72 시간에서 모두

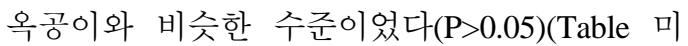
제시).

Table 2에 나타난 폐배지와 배지에 사용된 원료의 소실율 차이는 배지에 첨가된 부원료의 차이, 실험에 이용된 반추위액의 차이, 균사체 에 의한 섬유소 분해에 따른 차이(김과 김, 1993; Crawford, 1981) 등에 의한 영향이라고 사 료된다.
Table 3. In situ ruminal disappearance at $24 \mathrm{hr}$ incubation of spent mushroom substrates according to the primary culture ingredient ${ }^{1), 2 \text { ) }}$

\begin{tabular}{ccccc}
\hline & \multicolumn{2}{c}{ Primary culture ingredient ${ }^{3)}$} & \multirow{2}{*}{ SE } \\
\cline { 2 - 4 } & Sawdust & Corn cob Cotton waste & \\
\hline \hline & $\ldots \ldots \ldots \ldots \ldots \ldots \ldots$ & $\% \ldots \ldots \ldots \ldots \ldots \ldots$ \\
DMD & $15.1^{\mathrm{c}}$ & $34.1^{\mathrm{a}}$ & $25.6^{\mathrm{b}}$ & 3.0 \\
NDFD & $14.6^{\mathrm{c}}$ & $34.1^{\mathrm{a}}$ & $22.4^{\mathrm{b}}$ & 4.6 \\
ADFD & $10.2^{\mathrm{c}}$ & $52.4^{\mathrm{a}}$ & $18.8^{\mathrm{b}}$ & 2.7 \\
\hline
\end{tabular}

1) Least square means of 4 observations.

2) $\mathrm{DMD}=$ dry matter disappearance; NDFD=neutral detergent fiber disappearance

3) Primary culture ingredients were $100 \%$ corn cob, $50 \sim 80 \%$ sawdust depending upon samples, and $100 \%$ cotton waste.

abc Means with different superscripts within the same row are significantly different $(\mathrm{P}<0.05)$.

3. 배지 주원료별 폐배지의 in situ DM, NDF, $\mathrm{ADF}$ 소실율

버섯 폐배지의 주원료별 in situ 소실율은 Table 3에 제시되어져 있다. 배양 24시간에서의 $\mathrm{DM}, \mathrm{NDF}, \mathrm{ADF}$ 소실율은 모두 옥공이 주원료 폐배지가 가장 높았고, 다음으로 폐면 주원료, 톱밥 주원료 폐배지 순이었다 $(\mathrm{P}<0.05)$. 3종의 폐배지 중 그 발생량이 매우 적은 옥공이 주 원료 폐배지를 제외한 2종의 폐배지, 즉 폐면 주원료 폐배지와 톱밥 주원료 폐배지를 구체 적으로 분석한 결과(Table 4) $\mathrm{DM}$ 소실율은 배 양 6시간에서 72 시간까지 모든 배양시간에서 폐면 주원료 폐배지가 훨씬 높게 $(\mathrm{P}<0.05)$ 나타 났다(Table 4). NDF 소실율은 폐면 주원료 폐 배지가 배양 24, 72시간에서 훨씬 높았다 $(\mathrm{P}<0.05) . \mathrm{ADF}$ 소실율은 배양 6시간을 제외한 모든 배양시간에서 폐면 주원료 폐배지가 톱 밥 주원료 폐배지 보다 훨씬 높았다 $(\mathrm{P}<0.05)$. 주원료에 상관없이 $\mathrm{DM}, \mathrm{NDF}, \mathrm{ADF}$ 소실율 모 두 배양 24시간까지는 서서히 증가하다가 이 후 48,72 시간까지는 급격히 증가하는 양상을 보였다. 
Table 4. In situ ruminal disappearance of spent mushroom substrates according to the primary culture ingredient ${ }^{1), 2)}$

\begin{tabular}{|c|c|c|c|}
\hline \multirow{2}{*}{$\begin{array}{c}\text { Incubation } \\
\text { time, hr }\end{array}$} & \multicolumn{2}{|c|}{$\begin{array}{c}\text { Primary culture } \\
\text { ingredient }\end{array}$} & \multirow[t]{2}{*}{ SE } \\
\hline & Sawdust & Cotton waste & \\
\hline & (......... & .. $\% \quad \ldots . . .$. & 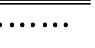 \\
\hline \multicolumn{4}{|l|}{ DMD } \\
\hline 6 & $11.2^{\mathrm{b}}$ & $20.2^{\mathrm{a}}$ & 1.0 \\
\hline 12 & $13.5^{\mathrm{b}}$ & $23.9^{\mathrm{a}}$ & 1.5 \\
\hline 24 & $15.1^{\mathrm{b}}$ & $25.6^{\mathrm{a}}$ & 2.0 \\
\hline 48 & $18.7^{\mathrm{b}}$ & $33.5^{\mathrm{a}}$ & 4.8 \\
\hline 72 & $24.9^{\mathrm{b}}$ & $42.5^{\mathrm{a}}$ & 6.8 \\
\hline \multicolumn{4}{|l|}{ NDFD } \\
\hline 6 & 11.8 & 16.5 & 3.9 \\
\hline 12 & 13.5 & 19.6 & 3.7 \\
\hline 24 & $14.6^{\mathrm{b}}$ & $22.4^{\mathrm{a}}$ & 3.7 \\
\hline 48 & 17.7 & 30.9 & 6.9 \\
\hline 72 & $24.7^{\mathrm{b}}$ & $42.0^{\mathrm{a}}$ & 6.8 \\
\hline \multicolumn{4}{|l|}{ ADFD } \\
\hline 6 & 8.1 & 11.2 & 3.6 \\
\hline 12 & $9.2^{\mathrm{b}}$ & $16.3^{\mathrm{a}}$ & 2.7 \\
\hline 24 & $10.2^{\mathrm{b}}$ & $18.8^{\mathrm{a}}$ & 2.7 \\
\hline 48 & $12.7^{\mathrm{b}}$ & $28.4^{\mathrm{a}}$ & 6.6 \\
\hline 72 & $17.8^{\mathrm{b}}$ & $39.2^{\mathrm{a}}$ & 6.7 \\
\hline \multicolumn{4}{|c|}{$\begin{array}{l}\text { 1) Least square means of } 4 \text { observations. } \\
\text { 2) } \mathrm{DMD}=\text { dry matter disappearance; } \\
\text { NDFD=neutral detergent fiber disappearance } \\
50 \sim 80 \% \text { sawdust depending upon samples; } 100 \% \\
\text { cotton waste. } \\
\text { ab Means with different superscripts within the same } \\
\text { row are significantly different }(\mathrm{P}<0.05) \text {. }\end{array}$} \\
\hline
\end{tabular}

폐배지 영양소의 분획을 살펴보면(Table 5) 폐면 주원료 폐배지 영양소는 톱밥 주원료 폐 배지 영양소와 비교해서 수용성(soluble) 분획 $(\mathrm{DM}$ 의 경우)과 가소화성(digestible) 분획(NDF, $\mathrm{ADF}$ 의 경우)이 뚜렷이 높고 $(\mathrm{P}<0.05)$, 비소화성 (non-digestible) 분획은 현저히 낮은 $(\mathrm{P}<0.05)$ 특 징을 보였는데, 이는 전술한 폐면 주원료 폐배 지의 높은 소실율을 잘 설명해 주고 있다.

폐배지 섬유소(NDF, $\mathrm{ADF})$ 의 가소화성 분획 의 분해율(degradation rate, $\% / \mathrm{hr}$ )과 예상되는 반 추위 분해율(estimated degradability, \%)은 Table 6에 제시되어져 있다. 폐배지 섬유소(NDF, $\mathrm{ADF})$ 의 가소화성 분획의 시간당 분해율(degradation rate, $\% / h r)$ 은 폐배지 종류 간에 차이가 없었다
Table 5. In situ fraction of DM, NDF and ADF in spent mushroom substrates according to the primary culture ingredient ${ }^{1)}$

\begin{tabular}{|c|c|c|c|}
\hline & \multicolumn{2}{|c|}{$\begin{array}{c}\text { Primary culture } \\
\text { ingredient }\end{array}$} & \multirow[t]{2}{*}{ SE } \\
\hline & Sawdust & Cotton waste & \\
\hline & $2 \ldots$. & $\% \ldots$ & $\cdots$ \\
\hline \multicolumn{4}{|l|}{ Dry matter fractions } \\
\hline $\begin{array}{l}\text { Water solubles and } \\
45 \mu \mathrm{m} \text { filterable }\end{array}$ & $10.2^{\mathrm{b}}$ & $17.7^{\mathrm{a}}$ & 0.5 \\
\hline Insoluble digestible & 14.7 & 24.8 & 6.0 \\
\hline Non-digestible & $75.1^{\mathrm{a}}$ & $57.5^{\mathrm{b}}$ & 6.5 \\
\hline \multicolumn{4}{|l|}{ NDF fractions } \\
\hline Digestible & $24.7^{\mathrm{b}}$ & $42.0^{\mathrm{a}}$ & 6.8 \\
\hline Non-digestible & $75.3^{\mathrm{a}}$ & $58.0^{\mathrm{b}}$ & 6.8 \\
\hline \multicolumn{4}{|l|}{$\mathrm{ADF}$ fractions } \\
\hline Digestible & $17.8^{\mathrm{b}}$ & $39.2^{\mathrm{a}}$ & 6.8 \\
\hline Non-digestible & $82.2^{\mathrm{a}}$ & $60.8^{\mathrm{b}}$ & 6.8 \\
\hline
\end{tabular}

1) Least square means of 4 observations.

2) $50 \sim 80 \%$ sawdust depending upon samples; $100 \%$ cotton waste.

ab Means with different superscripts within the same row are significantly different $(\mathrm{P}<0.05)$.

Table 6. Degradation rate of digestible fraction and estimated degradability of NDF and ADF in spent mushroom substrates according to the primary culture ingredient ${ }^{1)}$

\begin{tabular}{ll}
\hline & \multicolumn{2}{l}{ Primary culture ingredient } \\
\cline { 2 - 3 } Sawdust $\quad$ Cotton waste \\
\hline \hline$\ldots \ldots \ldots \ldots \ldots \ldots \%$
\end{tabular}

Degradation rate of digestible fraction, $\% / \mathrm{hr}$

\begin{tabular}{llll} 
NDF & 1.00 & 1.4 & 0.37 \\
ADF & 1.43 & 1.7 & 0.50 \\
\hline
\end{tabular}

Estimated degradability, \%

\begin{tabular}{|c|c|c|c|}
\hline \multicolumn{4}{|l|}{$\mathrm{K}_{p} \mathrm{~B}=0.025$} \\
\hline $\mathrm{NDF}$ & $7.2^{\mathrm{b}}$ & $14.8^{\mathrm{a}}$ & 3.8 \\
\hline $\mathrm{ADF}$ & $6.4^{\mathrm{b}}$ & $16.2^{\mathrm{a}}$ & 4.8 \\
\hline \multicolumn{4}{|l|}{$\mathrm{K}_{p} \mathrm{~B}=0.05$} \\
\hline $\mathrm{NDF}$ & $4.2^{\mathrm{b}}$ & $9.1^{\mathrm{a}}$ & 2.6 \\
\hline $\mathrm{ADF}$ & 5.6 & 11.0 & 3.5 \\
\hline
\end{tabular}

1) Least square means of 4 observations.

ab Means with different superscripts within the same row are significantly different $(\mathrm{P}<0.055)$. 
Table 7. Correlation coefficients between in vitro / in situ dry matter disappearance(DMD) or in vitro / in situ neutral detergent fiber disappearance (NDFD) and chemical composition of spent mushroom substrates

\begin{tabular}{|c|c|c|c|c|}
\hline \multirow{3}{*}{ Item } & \multicolumn{4}{|c|}{ Correlation coefficients $^{1)}$} \\
\hline & \multicolumn{2}{|c|}{ in vitro } & \multicolumn{2}{|c|}{ in situ } \\
\hline & DMD & NDFD & DMD & NDFD \\
\hline Organic matter & 0.23 & -0.27 & -0.80 & -0.81 \\
\hline Crude ash & -0.24 & 0.27 & 0.80 & 0.81 \\
\hline Crude protein & -0.34 & -0.73 & 0.15 & -0.12 \\
\hline Ether extract & 0.85 & 0.87 & 0.80 & 0.80 \\
\hline Neutral detergent fiber & -0.45 & -0.44 & -0.89 & -0.86 \\
\hline Acid detergent fiber & -0.80 & -0.78 & -0.93 & -0.84 \\
\hline Hemicellulose & 0.60 & 0.58 & -0.76 & -0.78 \\
\hline Cellulose & -0.52 & -0.47 & 0.60 & 0.73 \\
\hline Lignin & -0.90 & -0.90 & -0.87 & -0.91 \\
\hline Nonfibrous carbohydrate & 0.63 & 0.66 & 0.71 & 0.75 \\
\hline Total digestible nutrients & 0.80 & 0.78 & 0.93 & 0.84 \\
\hline
\end{tabular}

1) Pearson correlation(SAS, 2002).

$(\mathrm{P}<0.05)$.

폐배지 $\mathrm{NDF}$ 의 반추위에서의 예상 분해율 (degradability)은 가소화성 분획의 반추위 통과 속도 $\left(\mathrm{K}_{p} \mathrm{~B}\right)$ 가 0.025 또는 0.05 로 가정할 때 공히 폐면 주원료 폐배지가 톱밥 주원료 폐배지보다 배 이상 높은 것으로 나타났다 $(\mathrm{P}<0.055)$.

결과적으로 톱밥 주원료 폐배지와 비교해서 폐면 주원료 폐배지의 낮은 NDF, 높은 NFC 함 량, 그리고 낮은 비소화성 분획은 보다 높은 in vitro 및 in situ 건물 소실율을 유도하였다. 또 한 폐면 주원료 폐배지 섬유소는 lignin 함량과 비소화성 분획이 낮아서 in vitro $\mathrm{NDF}$ 소실율, in situ $\mathrm{NDF}, \mathrm{ADF}$ 소실율, 예상되는 반추위 분 해율 모두 상대적으로 높은 결과를 유도하였다.

\section{4. 폐배지의 in vitro / in situ 소실율과 화학 성분간의 상관관계}

In vitro 및 in situ 소실율은 사료의 in vivo 소화율과 높은 상관관계가 있는 것으로 알려져 있다(Van Soest 등, 1978; Gasa 등, 1989). 버섯 폐배지의 화학적 성분으로부터 사료 소화율을
예측할 목적으로 in vitro 와 in situ DM, NDF 소실율과 화학성분간의 상관관계를 분석한 결 과는 Table 7에 제시되어져 있다. 버섯 폐배지 의 in vitro 및 in situ $\mathrm{DMD}$ 와 $\mathrm{NDFD}$ 는 공히 분 석된 화학성분 중 $\mathrm{ADF}, \mathrm{NDF}$, lignin과 가장 높 은 부(-)의 상관관계를 보였다. 즉 버섯 폐배 지의 소화율을 예상하고자 할 때 화학성분 중 $\mathrm{ADF}, \mathrm{NDF}$, lignin이 중요한 지표로 활용될 수 있을 것이다.

\section{IV. 결 론}

화학성분 분석결과 버섯 폐배지는 고섬유소 저단백질 조사료원에 속하며, 폐배지 내의 섬 유소(NDF, ADF, Lignin)의 함량이 높을수록 폐 배지의 사료 영양적 가치는 떨어지는 것으로 사료된다. 발생량이 매우 적은 옥공이 또는 볏 짚 주원료 폐배지의 사료 영양적 가치는 폐면 또는 톱밥 주원료 폐배지 보다 높으며, 발생량 이 많은 폐면 또는 톱밥 주원료 폐배지 중에서 폐면 주원료 폐배지는 사료 영양적 가치가 상 대적으로 높았다. 그러므로 사료 영양적 가치 
가 높은 폐배지들을 우선적으로 가축 사료로 이용할 것을 권장한다. 향후 톱밥 주원료 폐배 지는 사료 영양적 가치의 개량 연구가 요구되 며, 사료 위생성과 저장 안전성 확보를 위해 버섯 폐배지의 적정한 가공처리방법의 개발이 요구된다.

$$
\text { V. 요 약 }
$$

본 연구에서는 느타리, 새송이 및 팽이버섯 폐배지를 버섯 종류별, 배지에 이용된 주원료 별로 나누어 반추가축 사료로서의 영양적 가치 를 구명하기 위해서 화학성분, in vitro 소실율 실험 및 in situ darcon bag 실험을 수행하였다. 버섯 폐배지는 고섬유소(NDF $64 \sim 78 \%$ ), 저단 백질(CP 7 11\%) 조사료원에 속하였다. 주원료 별 폐배지는 섬유소 성분이 가장 높은 톱밥 주 원료 폐배지와 비교해서 폐면 주원료 폐배지는 $\mathrm{NDF}$ 함량이 낮고 $(\mathrm{P}<0.05), \mathrm{NFC}$ 와 ash 함량이 높았다 $(\mathrm{P}<0.05)$. 버섯 폐배지의 화학적 성분은 전반적으로 버섯 종류보다는 주원료 종류에 의 해 주로 영향을 받았다. In vitro DM, NDF 소 실율은 분석된 배양시간(24, 48, 72 시간) 모두에 서 옥공이, 폐면, 톱밥 주원료 폐배지 순으로 높게 나타났다. In situ $\mathrm{DM}, \mathrm{NDF}, \mathrm{ADF}$ 소실율 은 배양 24시간에서 옥공이, 폐면, 톱밥 주원료 폐배지 순으로 높았다 $(\mathrm{P}<0.05)$. 톱밥 주원료 폐 배지와 비교해서 폐면 주원료 폐배지는 가소 화성 분획 $(\mathrm{NDF}, \mathrm{ADF})$ 이 뚜렷이 높고 $(\mathrm{P}<0.05)$ 비 소화성 분획은 현저히 낮았으며 $(\mathrm{P}<0.05)$, 그 결 과 배양 72 시간에서의 in situ $\mathrm{DM}, \mathrm{NDF}$ 소실율 (disappearance)과 예상 반추위 분해율(degradability) 도 현저히 높았다 $(\mathrm{P}<0.05)$. 결과적으로 폐면 주 원료 폐배지는 톱밥 주원료 폐배지 보다 반추 가축 조사료원으로서의 사료영양적 가치가 높 아 우선적 이용이 권장된다.

\section{VI. 인 용 문 헌}

1. AOAC. 1990. Official Methods of Analysis(15th Ed.). Association of official Analytical Chemists, Washington D.C.
2. Armentano, L. E., Herrington, T. A., Polan, C. E., Moe, A. J., Herbein J. H. and Umstadt, P. 1986. Ruminal degradation of dried brewers granins, wet brewers granins, and soybean meal. J. Dairy Sci. 69:2124-2133.

3. Caswell, L. E. 1990. Fungal additives. Feed Management. April 41(4):9-13.

4. Crawford, R. L. 1981. Lignin biodegradation and transformation. A Wiley-Inter Sci. Pub. New York. NY.

5. Gasa, J., Casstrillo, C., Baucells, M. D. and Guada, J. A. 1989. By-products from the canning industry as feedstuff for ruminants: digestibility and its prediction from chemical composition and laboratory bioassay. Anim. Feed Sci. Technol. 25:67-77.

6. Governot, T. R. 1997. Best practices for environmental protection in the mushroom farm community. Commonwealth of Pennsylvania.

7. Gupta, V. K. and Langar, P. N. 1988. Pleurotus florida for Upgrading the nutritive value of wheat straw. Biological Wastes 23:57-64.

8. Hadar, Y., Kerem, Z. and Gorodecki, B. 1993. Biodegradation of lignocellulosic agricultural wastes by Pleurotus ostreatus. Journal of Biotechnology 30:133-139.

9. Kahlon, S. S. and Dass, S. K. 1987, Biological conversion of paddy straw into feed. Biological Wastes 22:11-21.

10. Mertens, D. R. and Loften, J. R. 1980. The effect of starch on forage fiber digestion kinetics in vitro, J. Dairy Sci. 63:1437-1446.

11. Nocek, J. E. and English, J. E. 1986. In situ degradation kinetics: Evaluation of rate determination procedure, J. Dairy Sci. 69:77-87.

12. Ørskov, E. R., Hovell, F. D. and Mould, F. 1980. The use of the nylon bag technique for the evaluation of feedstuffs. Tropocal Animal Production 5:195-213.

13. Smith, L. W., Goering, H. K., Waldo, D. R. and Gordon, C. H. 1971. In vitro digestion rate of forage cell wall components, J. Dairy Sci. 54:71-79. 14. Tilley, J. M. A. and Terry, R. A. 1963. A two 
stage technique for the in vitro digestion of forage crops. J. Br. Grassl. Soc. 18:104-111.

15. Van Soest, P. J., Mertens, D. R. and Deinum, B. 1978. Preharvest factors influencing quality of conserted forage. J. Anim. Sci. 47(3):712-720.

16. Van Soest, P. J., Robertson, J. B. and Lewis, B. A. 1991. Methods of dietary fiber, neutral detergent fiber, and nonstarch polysaccharides in relation to animal nutrition. J. Dairy Sci. 74:3582-3597.

17. Williams, B. C., Mcmullan, J. T. and Mccahey, S. 2001. An initial assessment of spent mushroom compost as a potential energy feedstock. Bioresource Technology 79:227-230.

18. 김용국, 김용인. 1993. Mycelium에 의한 Lignocellulose 물질로부터 양질의 발효사료 생산. 한국낙농학회 지. 15(4):251-260.
19. 농림부. 2005. 2004 특용작물생산실태.

20. 송만강, 조남석. 1997. 볏짚에 대한 자기가수분해 처리 표고버섯 폐골목의 대치가 면양에서의 대 사적 반응과 성장에 미치는 효과. 한국영양사료 학회지. 21(6):525-532.

21. 윤승락. 1996. 표고버섯 재배 톱밥 폐배지의 가 축 조사료 이용. 월간 축산인. 2월호 :124.

22. 임광철, 라창식, 길준민, 김병완, 권응기, 신종서, 홍병주. 1998. 표고버섯 폐기목 균을 이용한 호 기성 처리가 볏짚의 반추위내 분해 특성에 미치 는 영향. 한국축산학회지. 40(4)381-390.

23. 정근기. 2003. 한우 경쟁력 제고 기술개발. 농림 부 최종보고서.

(접수일자 : 2006. 1. 24. / 채택일자 : 2006. 3. 20.) 